\title{
Topiramate heterocyclic analogues: synthesis and spectroscopic characterization
}

\author{
Miriam A. Martins Alho and Norma D'Accorso* \\ Centro de Investigaciones en Hidratos de Carbono (CIHIDECAR-CONICET), \\ Departamento de Química Orgánica, FCEN, UBA, Intendente Güiraldes 2160, \\ Ciudad Universitaria, C1428EGA Buenos Aires, Argentina \\ E-mail:nbdac@yahoo.com,norma@qo.fcen.uba.ar
}

Regional Issue: Organic Chemistry in Argentina

\begin{abstract}
Herein we describe the synthesis of a set of heterocyclic analogues of topiramate as possible therapeutic agents for epileptic seizure treatment. The new compounds and their precursors were characterized by physical, as well as spectroscopic techniques. We verified that the preferential conformation in solution of the carbohydrate ring is twist-boat. The stereochemistry of the new asymmetric centre, generated during the heterocyclizations, was proposed using NOESY experiment. These novel compounds could help to elucidate the mechanism of action of the commercial drug used for this disease.
\end{abstract}

Keywords: Topiramate, D-fructose, heterocyclic rings, spectroscopic data

\section{Introduction}

Anticonvulsants are the primary drugs used for the treatment of epileptic disorders. ${ }^{1}$ A wide diversity of chemical structures, including heterocycles, exhibits anticonvulsant activity. ${ }^{2}$ Bruce E. Maryanoff et al., ${ }^{3}$ reported the synthesis and biological activity studies of an anticonvulsant called "topiramate", a sulfamate monosaccharide derivative (Figure 1), which is used for epilepsy treatment.

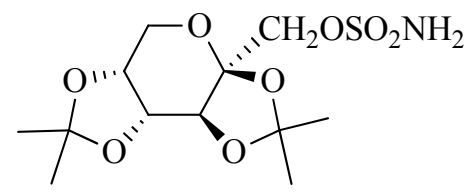

Figure 1. Chemical structure of topiramate. 
Despite the fact that topiramate is structurally unrelated to other antiepileptic drugs and its biological molecular mechanism of action is still unknown, ${ }^{4}$ several studies showed that this drug acts by multiple neurostabilizing mechanisms, including the blockade of voltage-dependent sodium channels, potentiation of $\gamma$-aminobutyric acid (GABA) derived neuroinhibition, antagonistic effects on the $\alpha$-amino-3-hydroxy-5-methyl-4-isoxazolepropionic acid/kainite receptor, which is a non- $N$-methyl-D-aspartic acid type receptor for glutamate and inhibition of carbonic anhydrase.$^{5-8}$ However, the pharmacology of topiramate appears to be complex and some of its pharmacodynamic actions still remain to be further elucidated. ${ }^{9-11}$

In addition, this substance is currently being evaluated for its effectiveness in various neurological and psychiatric disorders including alcohol dependence, body weight reduction and smoking. ${ }^{12-14}$

Beyond these medical applications, in recent years cognitive effects in low-dose topiramate treatments have been reported. ${ }^{15}$ On the other hand, Kockelmann et al., ${ }^{16}$ reported that the withdrawal of this drug caused significant improvement in frontal lobe associated measures like verbal fluency and working memory. Very recently, Beer et al., ${ }^{17}$ described a case of a fatal topiramate poisoning, so it will be necessary to establish the potential lethal topiramate concentrations.

Given the multiple etiologies of epilepsy, the limited understanding of the mechanisms behind this disorder and the adverse effects of the topiramate, the search for less toxic, more efficient agents for the treatment of seizure disorders is an ongoing endeavor. In this context, the aim of this work was to synthesize novel derivatives of topiramate where the C-1 of fructose was used to build heterocycles. We also proposed the preferential conformational in solution of the carbohydrate moiety from measured coupling constants of ${ }^{1} \mathrm{H}$ NMR spectra and determined the configuration of the new stereocentres generated during the heterocyclization reactions.

\section{Results and Discussion}

To carry out this project we chose some heterocycles which were obtained by functionalizing C-1 of 2,3:4,5-di-O-isopropylidene- $\beta$-D-fructopyranose 1 . One of these heterocycles was tetrazole, which is well known as a bioisoster of carboxylic acids ${ }^{18}$ and Hallberg et al. reported the use of acylsulfonamide and tetrazole as isosteric groups. ${ }^{19}$ Since the mechanism of action of topiramate is unknown, taking into account the diversity of structures with anticonvulsivant properties, we synthesized a set other heterocyclic derivatives with potential biological interest. ${ }^{20}$ In Scheme 1 we show the total synthetic pathway from compound $\mathbf{1}$ as the starting material. 


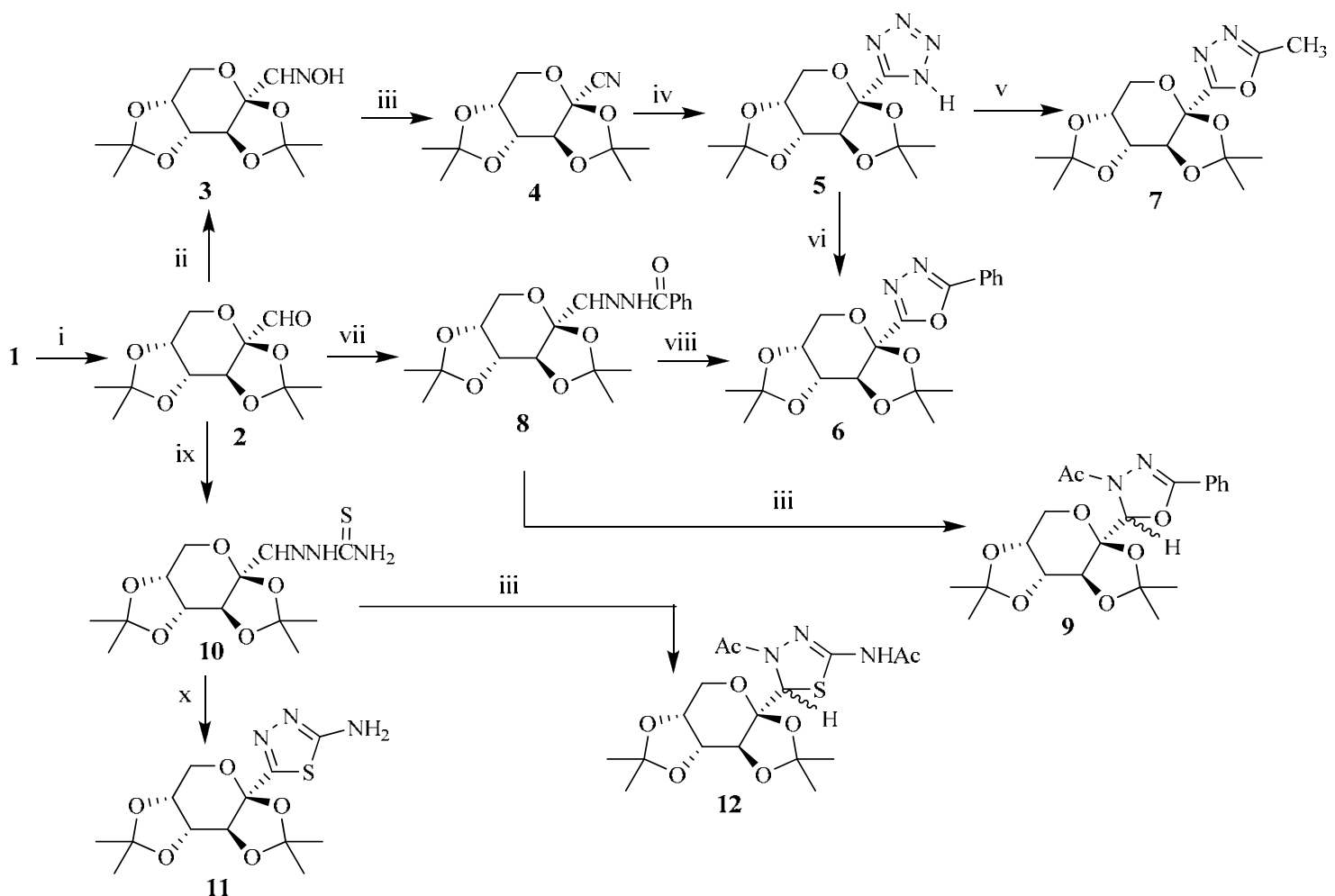

Scheme 1. i. $o$-iodoxybenzoic acid (IBX)/EtOAc; ii. $\mathrm{H}_{2} \mathrm{NOH} . \mathrm{HCl} / \mathrm{NaHCO}_{3} / \mathrm{EtOH}$; iii. $\mathrm{Ac}_{2} \mathrm{O} / \mathrm{Py}$; iv. $\mathrm{NaN}_{3} / \mathrm{NH}_{4} \mathrm{Cl} / \mathrm{DMF}$; v. $\mathrm{Ac}{ }_{2} \mathrm{O}$; vi. $\mathrm{BzCl} / \mathrm{Py}$; vii. $\mathrm{BzNHNH} \mathrm{NH}_{2} / \mathrm{CH}_{2} \mathrm{Cl}_{2}$; viii. phenyliodine diacetate (PIDA) $/ \mathrm{NaOAc} \cdot 3 \mathrm{H}_{2} \mathrm{O} / \mathrm{MeOH}$; ix. thiosemicarbazide/EtOH; x. $\mathrm{FeCl}_{3} \cdot 6 \mathrm{H}_{2} \mathrm{O} / \mathrm{EtOH} / \mathrm{Py}$.

To synthesize the heterocyclic derivatives we applied simple and efficient methods that we have already used to prepare other carbohydrate products. Synthesis of compound $\mathbf{2}$ was previously described by oxidation of 2,3:4,5-di-O-isopropylidene- $\beta$-D-fructopyranose, using pyridinium chlorochromate $\left(77.5 \%\right.$ yield). ${ }^{21}$ Looking for an eco-friendly and a more efficient oxidization we used $o$-iodoxybenzoic acid (IBX) as an oxidizing agent to replace the use of chromium salts. We obtained quantitative recovering of the crude product $(94 \%$ yield after purification). 1,2:3,4-Di-O-isopropylidene-1-(tetrazol-5'-yl)- $\beta$-D-arabinopyranose $\mathbf{5}$ was obtained by 1,3-dipolar cycloaddition using a methodology described in a previous paper. ${ }^{22}$

Other derivatives were the 2,5 disubstituted-1,3,4 oxadiazoles like 1,2:3,4-di-Oisopropylidene-1-(2'-phenyl-1', $3^{\prime}, 4^{\prime}$-oxadiazol)-5'-yl- $\beta$-D-arabinopyranose 6 and the $2^{\prime}$-methyl$1^{\prime}, 3^{\prime}, 4^{\prime}$-oxadiazole analogue 7 were synthesized by acylation of compound 5 (see Experimental Section). Compound $\mathbf{6}$ was also obtained by oxidative cyclization of the corresponding benzoyl hydrazone derivative 8 using phenyliodine diacetate (PIDA), but in this case the yield was unsatisfactory. The acylation of compound 8 led to 1 - $\left(N\right.$-acetyl-2'-phenyl-4', $5^{\prime}$-dihydro-1', $3^{\prime}, 4^{\prime}-$ oxadiazol)-5'-yl-1,2:3,4-di- $O$-isopropylidene- $\beta$-D-arabinopyranose $9 \mathbf{a}$ and $\mathbf{9 b}$.

On the other hand, the 1-(2'-amino-1',3',4'-thiadiazol)-5'-yl-1,2:3,4-di-O-isopropylidene- $\beta$ D-arabinopyranose 11 and their non-aromatic analogues 12a and 12b were synthesized from the 
corresponding thiosemicarbazone 10 using the methodology previously described. ${ }^{23}$ In Structure Block 1 we show the numbering applied for the carbohydrate and heterocyclic moieties.

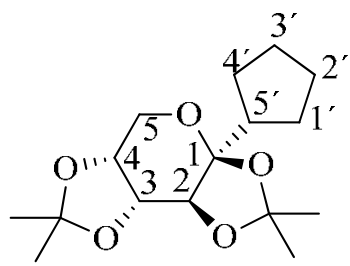

Structure Block 1. Numbering of heterocyclic derivatives.

${ }^{1}$ H NMR data (chemical shifts, multiplicities and coupling constants) of compounds 5-7, 9a, 9b, 11, 12a and 12b are listed in Table 1, and meanwhile the spectroscopic data of the precursors are reported in the Experimental Section.

Table 1. ${ }^{1}$ H NMR data of heterocyclic derivatives 5-7, 9a, 9b, 11, 12a and 12b

\begin{tabular}{|c|c|c|c|c|c|c|c|}
\hline & $\mathrm{H}-2$ & $\mathrm{H}-3$ & $\mathrm{H}-4$ & $\mathrm{H}-5 \mathrm{a}$ & $\mathrm{H}-5 \mathrm{~b}$ & H-5' & $\mathrm{N}-\mathrm{H}$ \\
\hline \multirow{3}{*}{$5^{\mathrm{a}}$} & 4.98 & 4.67 & 4.34 & 4.05 & 3.94 & & 10.51 \\
\hline & $\mathrm{d}, \mathrm{J}_{2,3} 2.2$ & $\mathrm{dd}, \mathrm{J}_{3,4} 7.9$ & $\mathrm{dd}, \mathrm{J}_{4,5 \mathrm{a}} 1.0$ & $\mathrm{dd}, \mathrm{J}_{5 \mathrm{a}, 5 \mathrm{~b}} 13.0$ & $\mathrm{~d}, \mathrm{~J}_{4,5 \mathrm{~b}} 0.0$ & & $\mathrm{~s}(\mathrm{br})$ \\
\hline & 5.11 & 4.72 & 4.33 & 4.06 & 3.91 & & \\
\hline \multirow[t]{2}{*}{$6^{\mathrm{a}}$} & $\mathrm{d}, \mathrm{J}_{2,3} 2.5$ & $\mathrm{dd}, \mathrm{J}_{3,4} 8.0$ & $\begin{array}{c}\mathrm{d}(\mathrm{br}) \\
\mathrm{J}_{4,5 \mathrm{a}} 1.8\end{array}$ & $\mathrm{dd}, \mathrm{J}_{5 \mathrm{a}, 5 \mathrm{~b}} 13.0$ & $\mathrm{~d}, \mathrm{~J}_{4,5 \mathrm{~b}} 0.6$ & & \\
\hline & 5.03 & 4.69 & 4.31 & 4.02 & 3.91 & & \\
\hline \multirow[t]{2}{*}{$7^{\mathrm{a}}$} & $\mathrm{d}, \mathrm{J}_{2,3} 2.4$ & $\mathrm{dd}, \mathrm{J}_{3,4} 8.0$ & $\begin{array}{c}\text { ddd } \\
\mathrm{J}_{4,5 \mathrm{a}} 1.6\end{array}$ & $\mathrm{dd}, \mathrm{J}_{5 \mathrm{a}, 5 \mathrm{~b}} 13.0$ & $\mathrm{~d}, \mathrm{~J}_{4,5 \mathrm{~b}} 0.9$ & & \\
\hline & 4.75 & 4.61 & 4.22 & 3.82 & 3.77 & 6.46 & \\
\hline \multirow[t]{2}{*}{$9 a^{b}$} & $\mathrm{~d}, \mathrm{~J}_{2,3} 2.5$ & $\mathrm{dd}, \mathrm{J}_{3,4} 7.8$ & $\mathrm{dd}, \mathrm{J}_{4,5 \mathrm{a}} 1.4$ & $\mathrm{dd}, \mathrm{J}_{5 \mathrm{a}, 5 \mathrm{~b}} 13.0$ & $\mathrm{~d}, \mathrm{~J}_{4,5 \mathrm{~b}} 0.0$ & $\mathrm{~s}$ & \\
\hline & 4.72 & 4.62 & 4.25 & 3.92 & 3.76 & 6.46 & \\
\hline \multirow[t]{2}{*}{$9 b^{b}$} & $\mathrm{~d}, \mathrm{~J}_{2,3} 2.5$ & $\mathrm{dd}, \mathrm{J}_{3,4} 7.8$ & $\mathrm{dd}, \mathrm{J}_{4,5 \mathrm{a}} 1.8$ & $\mathrm{dd}, \mathrm{J}_{5 \mathrm{a}, 5 \mathrm{~b}} 13.0$ & $\mathrm{~d}, \mathrm{~J}_{4,5 \mathrm{~b}} 0.0$ & $\mathrm{~s}$ & \\
\hline & 4.99 & 4.65 & 4.27 & 4.02 & 3.91 & & 5.62 \\
\hline \multirow[t]{2}{*}{$11^{\mathrm{a}}$} & $\mathrm{d}, \mathrm{J}_{2,3} 2.2$ & $\mathrm{dd}, \mathrm{J}_{3,4} 7.9$ & $\mathrm{dd}, \mathrm{J}_{4,5 \mathrm{a}} 0.0$ & $\mathrm{dd}, \mathrm{J}_{5 \mathrm{a}, 5 \mathrm{~b}} 13.0$ & $\mathrm{~d}, \mathrm{~J}_{4,5 \mathrm{~b}} 0.0$ & & $\mathrm{~s}(\mathrm{br})$ \\
\hline & 4.89 & 4.49 & 4.15 & 3.79 & 3.71 & 6.19 & 8.48 \\
\hline \multirow[t]{2}{*}{$12 a^{b}$} & $\mathrm{~d}, \mathrm{~J}_{2,3} 2.5$ & $\mathrm{dd}, \mathrm{J}_{3,4} 7.9$ & $\mathrm{dd}, \mathrm{J}_{4,5 \mathrm{a}} 2.0$ & $\mathrm{dd}, \mathrm{J}_{5 \mathrm{a}, 5 \mathrm{~b}} 13.1$ & $\mathrm{~d}, \mathrm{~J}_{4,5 \mathrm{~b}} 0.0$ & $\mathrm{~s}$ & $\mathrm{~s}(\mathrm{br})$ \\
\hline & 4.68 & 4.62 & 4.22 & 4.22 & 3.76 & 6.22 & 8.97 \\
\hline $12 b^{b}$ & $\mathrm{~d}, \mathrm{~J}_{2,3} 2.9$ & $\mathrm{dd}, \mathrm{J}_{3,4} 7.8$ & $\mathrm{dd}, \mathrm{J}_{4,5 \mathrm{a}} 1.7$ & $\mathrm{dd}, \mathrm{J}_{5 \mathrm{a}, 5 \mathrm{~b}} 13.1$ & $\mathrm{~d}, \mathrm{~J}_{4, \mathbf{5 b}} 0.0$ & $\mathrm{~S}$ & $\mathrm{~s}(\mathrm{br})$ \\
\hline
\end{tabular}

${ }^{\text {a }}$ Performed at $200 \mathrm{MHz}$.

${ }^{\mathrm{b}}$ Performed at $500 \mathrm{MHz}$.

From the analysis of coupling constants listed in Table 1, we can conclude that in all derivatives, the carbohydrate moiety have a twist-boat preferential conformation in solution. 
Maryanoff and col. reported the same conformation for the carbohydrate moiety of topiramate, and they concluded that this conformation is very important for the pharmacologic activities. ${ }^{3}$ In our cases, we observed that the presence of heterocyclic rings does not affect the carbohydrate conformation, so these new compounds are very promising for future biological applications.

In a previous work, ${ }^{24}$ we studied the sensitivity to steric hindrance on the oxo- and thioheterocyclization reactions to synthesize spiro heterocycles. We found that the heterocyclizations of pyranose and furanose thiosemicarbazones are more sensitive to a crowded environment, so a single thiadiazoline ring was obtained. Cyclization of the corresponding benzoylhydrazone under standard conditions $\left(110^{\circ} \mathrm{C}\right)$ demonstrated no diastereoselectivity, although the application of a more energetic procedure (reflux) gave only one isomer.

The standard procedure performed on compound $\mathbf{8}$, gave a crude reaction mixture which showed the presence of compound $9 \mathbf{a}$ and $\mathbf{9 b}$ (4:1 ratio) under spectroscopic analysis, meanwhile the reaction carried out at reflux shows exclusively one isomer 9a. In order to determine the configuration of the new stereocentre we performed a NOESY experiment on the isolated single isomer. This allowed us to propose the $S$ configuration for the main compound. Figure 2 shows the spectroscopic correlations.

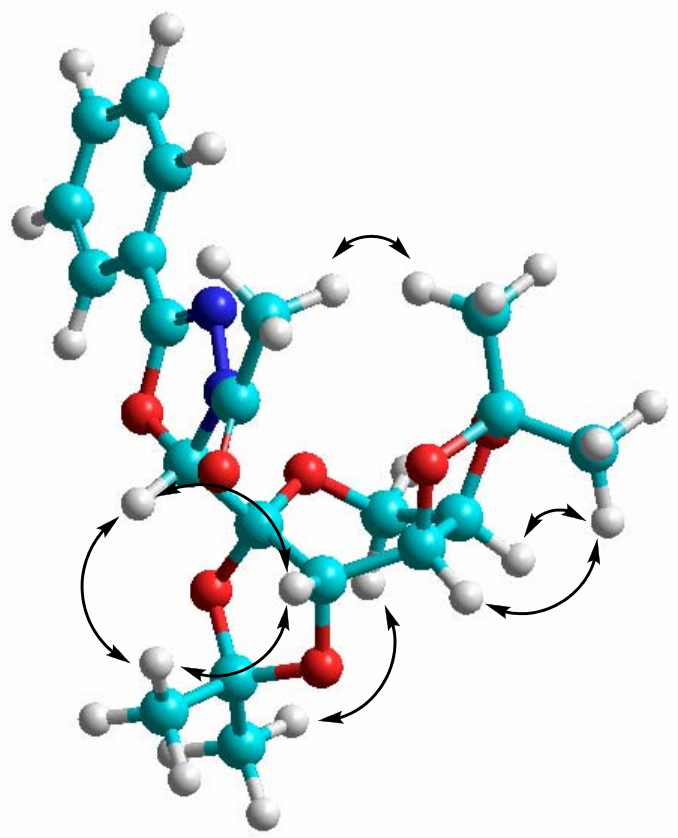

Figure 2. NOESY correlations for compound 9a.

For this reaction we did not expect any diastereoselection, because the cyclization takes place on an exocyclic plane carbon, but the relative selectivity observed for cyclization of $\mathbf{8}$ at $110^{\circ} \mathrm{C}$ was unexpected. Because of this we calculated the minimized geometries of the two possible diastereoisomers of $\mathbf{8}$, and found that the anti form was the less energetic. The conformation of 
the more stable rotamer is shown in Figure 3. It can be observed that the isopropylidene group, to a certain extent, shields one side of the imine bond inhibiting the approach of the oxygen. If oxygen attacks by the less sterically hindered side, the main compound resulting from the heterocyclization reaction must be the $S$ isomer, which is consistent with the configuration obtained from NOESY spectrum.
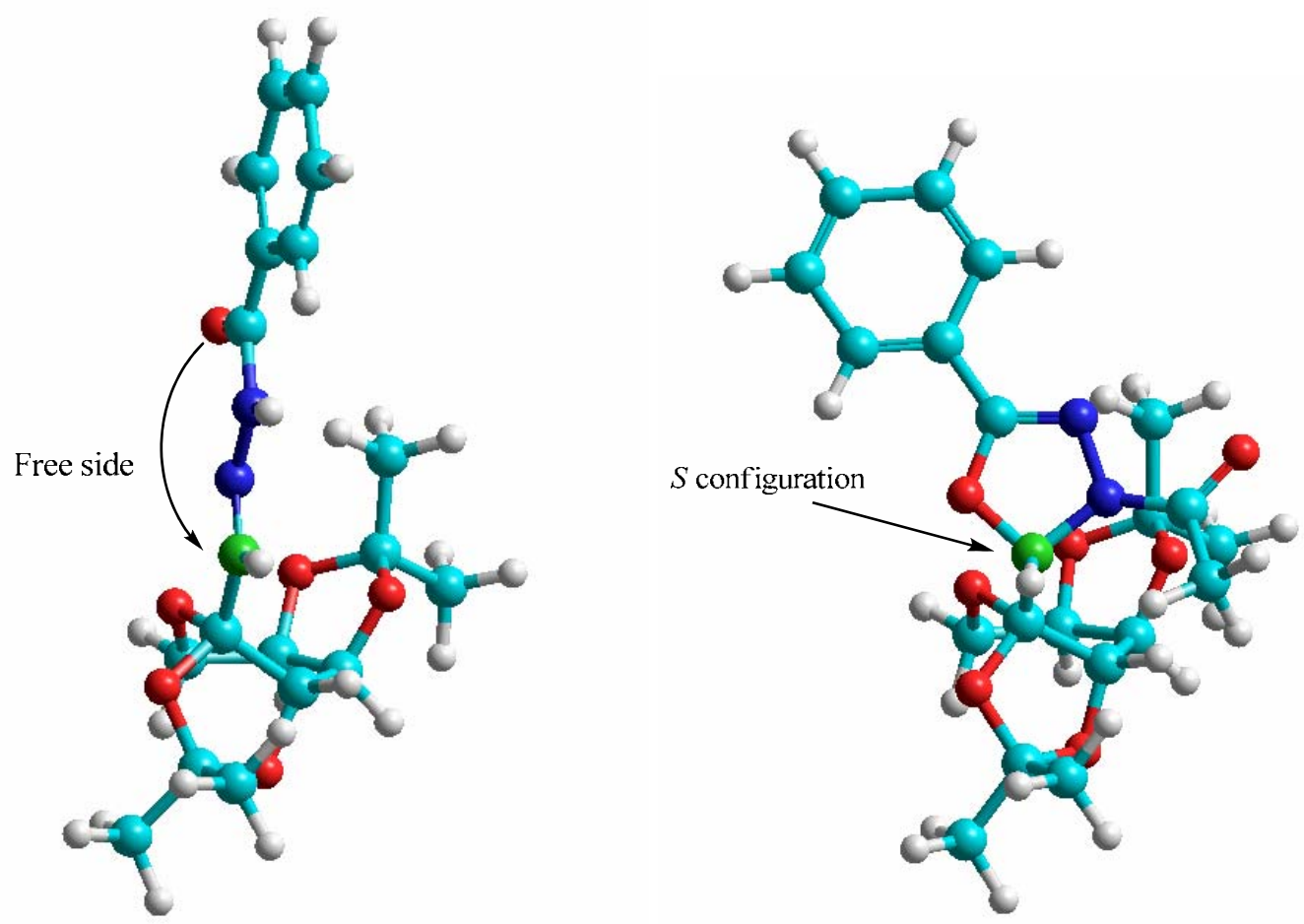

Figure 3. Less energetic conformer for anti isomer of compound $\mathbf{8}$ and its main cyclization product, compound $9 \mathbf{a}$.

The application of standard procedure on compound 10, gave a crude reaction mixture which showed the presence of both diastereoisomers $\mathbf{1 2 a}$ and $\mathbf{1 2 b}$, and found that the relationship between both isomers did not change when a higher temperature was used (62:38 or 61:39 ratio, respectively). The NOESY experiment carried out on the mixture let us to propose the $R$ configuration for the main compound (Figure 4). 


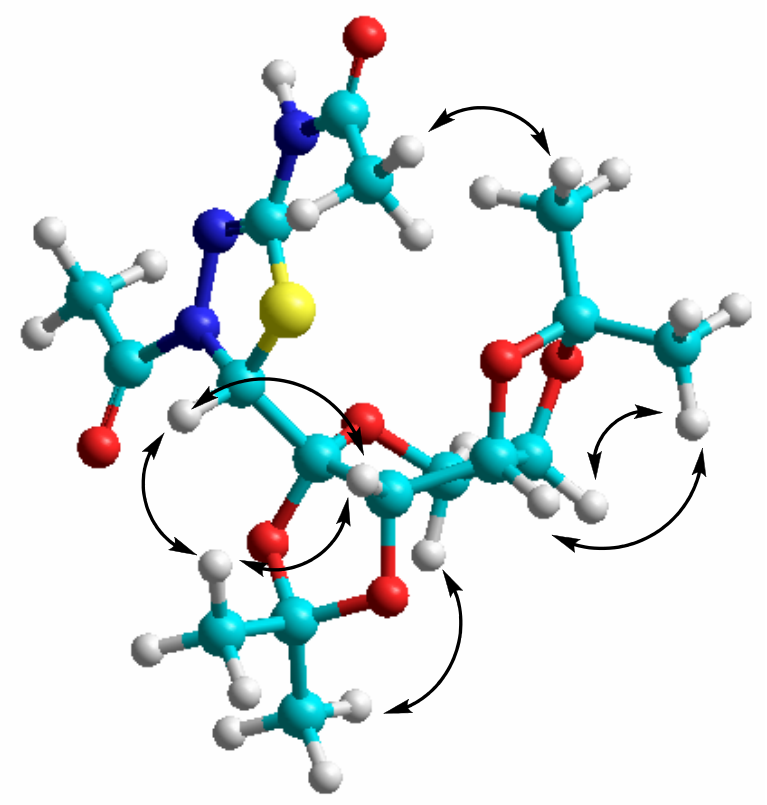

Figure 4. NOESY correlations for compound 12a.

We tried to determine the reason of the slight preference for the $R$ isomer and we found that the conformation of the lower energy rotamer for anti configuration of $\mathbf{1 0}$ seem to be reactive on both sides. However, a little steric hindrance on one side can be observed (Figure 5). This attack generates a slight preference by the $\mathrm{R}$ isomer.
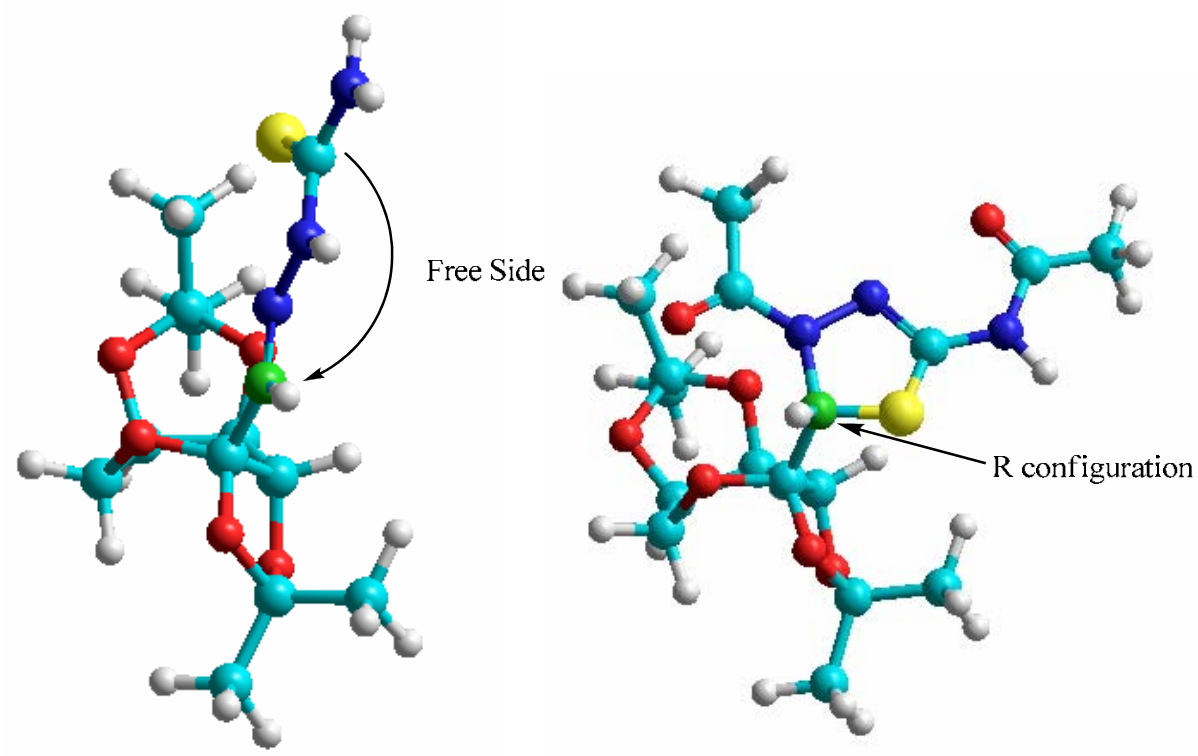

Figure 5. Less energetic conformer for anti isomer of compound $\mathbf{1 0}$ and its main cyclization product, compound $\mathbf{1 2 a}$. 


\section{Conclusions}

A new group of heterocyclic analogues of topiramate were efficiently synthesized from 2,3:4,5di-O-isopropylidene- $\beta$-D-fructopyrnose. These new derivatives were characterized physically and spectroscopically using homo and heteronuclear techniques. From the conformational analysis we can observe that in all cases the sugar ring has the required twist-boat conformation to show biological activity. Therefore, we suppose that this set of compounds can help elucidate the mechanism of action of this drug of clinical use.

\section{Experimental Section}

General. Synthesis of compounds 2-12 were carried out using all solvents and reagents as purchased, without further purification. Analytical TLC was conducted on Silica Gel 60G (Merck) on precoated plates and visualization was made by UV light and ethanol/sulfuric acid $(10: 1)$ or cerium molybdate followed by heating. Flash-chromatographic separations were performed on Silica Gel $60 \mathrm{G}$ (Merck). Elemental analysis was performed on an Exeter Analytical CE-440 elemental analyzer. Optical rotations were recorded at $20{ }^{\circ} \mathrm{C}$ on a Perkin Elmer 343 polarimeter, and melting points were uncorrected. ${ }^{1} \mathrm{H},{ }^{13} \mathrm{C}$ NMR spectra were recorded in deuterochloroform on a Bruker AC-200 spectrometer, operating at $200,50 \mathrm{MHz}$ respectively; or a Bruker AMX-500 spectrometer, operating at 500, $125 \mathrm{MHz}$ respectively. Assignments of the ${ }^{1} \mathrm{H}$ and ${ }^{13} \mathrm{C}$ NMR spectra were confirmed with the aid of two dimensional techniques ${ }^{1} \mathrm{H},{ }^{13} \mathrm{C}$ (COSY, HSQC). Chemical shifts $(\delta)$ are reported in parts per million downfield from tetramethyl silane as internal standard. Minimum energy structures were founded with HyperChem 8.0.3, using MM+ force field.

2,3:4,5-Di-O-isopropylidene- $\beta$-D-arabino-hexos-2-ulo-2,6-pyranose (2). 2,3:4,5-Di- $O$-isopropylidene- $\beta$-D-fructopyranose $(1.98 \mathrm{~g}, 7.5 \mathrm{mmol})$ was dissolved in ethyl acetate $(40 \mathrm{~mL})$, and IBX $(7.1 \mathrm{~g})$ was added. The mixture was stirred and heated at reflux for $5 \mathrm{~h}$, then, the solid was filtered and crude 2 was obtained by evaporation, with a quantitative recovery. The syrup was purified by dry flash chromatography, using mixtures of cyclohexane:acetone and was obtained as a syrup $(1.89 \mathrm{~g} ; 96 \%)$ and their NMR signals are consistent with those reported in literature. ${ }^{21}$

2,3:4,5-Di- $O$-isopropylidene- $\beta$-D-arabino-hexos-2-ulo-2,6-pyranose oxime (3). Compound 2 $(0.81 \mathrm{~g}, 3.1 \mathrm{mmol})$ was dissolved in ethanol $(15 \mathrm{~mL})$, and then hydroxylamine hydrochloride $(0.285 \mathrm{~g}, 4.1 \mathrm{mmol})$ and sodium bicarbonate $(0.420 \mathrm{~g}, 5.0 \mathrm{mmol})$ were added with stirring and left $3 \mathrm{~h}$ at room temperature. The salts were filtered and the solution was evaporated. The syrupy residue was dissolved in $\mathrm{CH}_{2} \mathrm{Cl}_{2}$, filtered and purified by dry flash chromatography, using mixtures of cyclohexane:acetone. Compound 3 crystallizes from cyclohexane:acetone as

colorless crystals $(0.81 \mathrm{~g})$. Yield $94 \%$; mp $137-138{ }^{\circ} \mathrm{C},[\alpha]_{\mathrm{D}}{ }^{20}-0.42\left(1.1, \mathrm{CHCl}_{3}\right) ;{ }^{1} \mathrm{H}$ NMR $\delta$ 1.35, 1.38, 1.46, 1.55 (four s, $\left.12 \mathrm{H},-\mathrm{C}\left(\mathrm{C}_{3}\right)_{2}\right), 3.79$ (dd, $J=1.0 \mathrm{~Hz}$ and $13.0 \mathrm{~Hz}, 1 \mathrm{H}, \mathrm{H}-6 \mathrm{~b}$ ), 3.93 
(dd, $J=1.8 \mathrm{~Hz}$ and $13.0 \mathrm{~Hz}, 1 \mathrm{H}, \mathrm{H}-6 \mathrm{a}), 4.27$ (br d, $J=7.8 \mathrm{~Hz}, 1 \mathrm{H}, \mathrm{H}-5), 4.63$ (dd, $J=2.6 \mathrm{~Hz}$ and $7.4 \mathrm{~Hz}, 1 \mathrm{H}, \mathrm{H}-4), 4.66(\mathrm{~d}, J=2.2 \mathrm{~Hz}, 1 \mathrm{H}, \mathrm{H}-3)$; ${ }^{13} \mathrm{C} \mathrm{NMR} \delta 24.3,24.7,25.9,26.1(-$ $\left.\mathrm{C}\left(\underline{\mathrm{C}}_{3}\right)_{2}\right), 61.1$ (C-6), 70.1 (C-4), 70.5 (C-5), 71.7 (C-3), $100.4(\mathrm{C}-2), 109.1,109.3\left(-\underline{\mathrm{C}}\left(\mathrm{CH}_{3}\right)_{2}\right)$, 149.5 (C-1). Anal. Calcd. for $\mathrm{C}_{12} \mathrm{H}_{19} \mathrm{NO}_{6}$ : C, 52.7; H, 7.0; N, 5.1. Found: C, 53.0; H, 6.9; N, $5.3 \%$.

2,3:4,5-Di-O-isopropylidene- $\beta$-D-arabino-hex-2-ulosonitrile (4). Compound 4 was prepared dissolving compound $3(0.60 \mathrm{~g}, 2.3 \mathrm{mmol})$ in pyridine $(1 \mathrm{~mL})$ and acetic anhydride $(1 \mathrm{~mL})$. The mixture was heated at reflux, and the reaction was followed by TLC (cyclohexane:acetone 7:3), and stopped by addition of ethanol. The reaction media was evaporated at reduced pressure and the remains of acetic acid were removed by addition of toluene and evaporation. The syrup was purified by dry flash chromatography, using mixtures of cyclohexane:acetone. Pure compound 4 was obtained as syrup $(0.41 \mathrm{~g})$. Yield $73 \% ;[\alpha]_{\mathrm{D}}{ }^{20}-0.53\left(1.2, \mathrm{CHCl}_{3}\right),{ }^{1} \mathrm{H}$ NMR $\delta 1.35,1.48$, 1.52, 1.54 (four s, $\left.12 \mathrm{H},-\mathrm{C}\left(\mathrm{C}_{3}\right)_{2}\right), 3.78(\mathrm{dd}, J=1.8 \mathrm{~Hz}$ and $13.0 \mathrm{~Hz}, 1 \mathrm{H}, \mathrm{H}-6 \mathrm{~b}), 3.82(\mathrm{dd}, J=$ $1.2 \mathrm{~Hz}$ and $13.0 \mathrm{~Hz}, 1 \mathrm{H}, \mathrm{H}-6 \mathrm{a}), 4.26(\mathrm{dt}, J=7.9 \mathrm{~Hz}$ and $1.3 \mathrm{~Hz}, 1 \mathrm{H}, \mathrm{H}-5), 4.61(\mathrm{~d}, J=2.0 \mathrm{~Hz}$, $1 \mathrm{H}, \mathrm{H}-3), 4.64$ (dd, $J=2.3 \mathrm{~Hz}$ and $7.4 \mathrm{~Hz}, 1 \mathrm{H}, \mathrm{H}-4) ;{ }^{13} \mathrm{C} \mathrm{NMR} \delta 23.9,24.4,25.7,25.9(-$ $\left.\mathrm{C}\left(\underline{\mathrm{CH}}_{3}\right)_{2}\right), 61.4$ (C-6), 69.3 (C-4), 69.4 (C-5), 74.4 (C-3), 93.8 (C-2), 109.9, $111.5\left(-\underline{\mathrm{C}}\left(\mathrm{CH}_{3}\right)_{2}\right)$, 116.6 (C-1). Anal. Calcd. for $\mathrm{C}_{12} \mathrm{H}_{17} \mathrm{NO}_{5}$ : C, 56.5; H, 6.7; N, 5.5. Found: C, 56.8; H, 6.7; N, $5.8 \%$.

1,2:3,4-Di-O-isopropylidene-1-(tetrazol-5'-yl)- $\beta$-D-arabinopyranose (5). A mixture of compound 4 (0.47 g, $1.8 \mathrm{mmol}), \mathrm{NaN}_{3}(0.24 \mathrm{~g}, 3.7 \mathrm{mmol})$ and $\mathrm{NH}_{4} \mathrm{Cl}(0.20 \mathrm{~g}, 3.7 \mathrm{mmol})$ was suspended in DMF $(10 \mathrm{~mL})$ and heated at reflux with stirring for $1 \mathrm{~h}$. The reaction media was evaporated under reduced pressure; the residue was dissolved in $\mathrm{CH}_{2} \mathrm{Cl}_{2}$, filtered and evaporated. The syrup was purified by dry flash chromatography using mixtures of cyclohexane:acetone. Compound 5 crystallizes from cyclohexane:acetone $(0.44 \mathrm{~g})$. Yield $80 \% ; \mathrm{mp} 144-146{ }^{\circ} \mathrm{C},[\alpha]_{\mathrm{D}}{ }^{20}$ $-0.51\left(0.9, \mathrm{CHCl}_{3}\right),{ }^{1} \mathrm{H} \mathrm{NMR} \delta 1.20,1.28,1.57,1.59$ (four s, $\left.12 \mathrm{H},-\mathrm{C}\left(\mathrm{C}_{3}\right)_{2}\right) ;{ }^{13} \mathrm{C} \mathrm{NMR} \delta 23.7$, 24.8, 25.6, $26.1\left(-\mathrm{C}\left(\underline{\mathrm{CH}}_{3}\right)_{2}\right), 61.1$ (C-5), 68.6 (C-3), 70.0 (C-4), 74.5 (C-2), 100.4 (C-1), 109.4 , $111.1\left(-\underline{C}\left(\mathrm{CH}_{3}\right)_{2}\right), 156.8\left(\mathrm{C}-5^{\prime}\right)$. Anal. Calcd. for $\mathrm{C}_{12} \mathrm{H}_{18} \mathrm{~N}_{4} \mathrm{O}_{5}: \mathrm{C}, 48.3 ; \mathrm{H}, 6.0 ; \mathrm{N}, 18.8$. Found: $\mathrm{C}$, $48.4 ; \mathrm{H}, 6.1 ; \mathrm{N}, 18.8 \%$.

1,2:3,4-Di-O-isopropylidene-1-(2'-phenyl-1',3',4'-oxadiazol)-5'-yl- $\beta$-D-arabinopyranose (6). Compound $\mathbf{6}$ was synthesized by acylation of compound 5 and by oxidative cyclization of compound 8.

\section{Synthesis of (6) by benzoylation of compound (5)}

Compound 5 ( $1.50 \mathrm{~g}, 5.03 \mathrm{mmol})$ was dissolved in pyridine $(15 \mathrm{~mL})$, and benzoyl chloride $(2.5$ $\mathrm{mL})$ was added. The mixture was heated in a water bath $\left(90{ }^{\circ} \mathrm{C} \pm 5\right)$ until disappearance of compound 5 (3-4 h). The reaction was finished by adding water, and the mixture was evaporated under reduced pressure. The residue was dissolved in $\mathrm{CH}_{2} \mathrm{Cl}_{2}$, extracted with $\mathrm{NaHCO}_{3}$ (sat), washed with water, dried with anhydrous $\mathrm{Na}_{2} \mathrm{SO}_{4}$, filtered and concentrated. The residue was purified by dry flash chromatography, using mixtures of cyclohexane:acetone. Compound $\mathbf{6}$ was obtained as amorphous solid. Yield $81 \%$; mp $111-113{ }^{\circ} \mathrm{C},[\alpha]_{\mathrm{D}}{ }^{20}-0.38\left(0.9, \mathrm{CHCl}_{3}\right),{ }^{1} \mathrm{H}$ NMR $\delta$ 
$1.34,1.39,1.52,1.62$ (four s, $\left.12 \mathrm{H},-\mathrm{C}\left(\mathrm{CH}_{3}\right)_{2}\right), 7.45-8.12\left(\mathrm{~m}, 5 \mathrm{H}\right.$, aromatics); ${ }^{13} \mathrm{C} \mathrm{NMR} \delta 24.3$, 24.6, 25.9, $26.1\left(-\mathrm{C}\left(\underline{\mathrm{CH}}_{3}\right)_{2}\right), 61.6$ (C-5), 70.0 (C-3), 70.2 (C-4), 73.2 (C-2), 98.0 (C-1), 109.5, $110.6\left(-\underline{C}\left(\mathrm{CH}_{3}\right)_{2}\right), 123.6,127.2,129.0,131.9$ (aromatic carbons), 164.5, 165.4 (C-2 and C-5). Anal. Calcd. for $\mathrm{C}_{19} \mathrm{H}_{22} \mathrm{~N}_{2} \mathrm{O}_{6}$ : C, 61.0; H, 5.9; N, 7.5. Found: C, 60.6; H, 6.0; N, 7.3\%.

\section{Synthesis of (6) by oxidative cyclization of compound (8)}

2,3:4,5-Di-O-isopropylidene- $\beta$-D-arabino-hexos-2-ulo-2,6-pyranose benzoylhydrazone 8 ( $0.10 \mathrm{~g}$, $0.26 \mathrm{mmol})$ was dissolved in methanol $(3 \mathrm{~mL})$. PIDA $(0.14 \mathrm{~g}, 0.43 \mathrm{mmol})$ and $\mathrm{NaOAc}_{3} \mathrm{H}_{2} \mathrm{O}$ $(0.11 \mathrm{~g}, 0.78 \mathrm{mmol})$ were added and left overnight at room temperature. The mixture was evaporated at reduced pressure and the solid washed with hexane and then with water. The residue was purified by dry flash chromatography, using mixtures of cyclohexane:acetone. Compound 6 was obtained $(0.04 \mathrm{~g})$. Yield $40 \%$.

1,2:3,4-Di-O-isopropylidene-1-(2'-methyl-1',3',4'-oxadiazol)-5'-yl- $\beta$-D-arabinopyranose (7). Compound 7 was obtained by dissolving compound $5(0.12 \mathrm{~g}, 0.4 \mathrm{mmol})$ in acetic anhydride (3 $\mathrm{mL}$ ) and heated at reflux for $1.5 \mathrm{~h}$. The reaction was stopped as described for compound 4. Compound 7 was purified by dry flash chromatography, using mixtures of cyclohexane:acetone (0.09 g). Yield 72\%; mp 100-102 ${ }^{\circ} \mathrm{C},[\alpha]_{\mathrm{D}}{ }^{20}-0.45\left(1.0, \mathrm{CHCl}_{3}\right),{ }^{1} \mathrm{H}$ NMR $\delta 1.33,1.37,1.46,1.59$ (four s, $\left.12 \mathrm{H},-\mathrm{C}\left(\mathrm{CH}_{3}\right)_{2}\right), 2.56\left(\mathrm{~s}, 3 \mathrm{H}\right.$, heterocyclic $\left.-\mathrm{CH}_{3}\right) ;{ }^{13} \mathrm{C} \mathrm{NMR} \delta 11.1$ (heterocyclic $-\mathrm{CH}_{3}$ ), 24.2, 24.6, 25.7, $26.0\left(-\mathrm{C}\left(\underline{\mathrm{CH}}_{3}\right)_{2}\right), 61.6(\mathrm{C}-5), 69.8$ (C-3), 70.0 (C-4), 73.0 (C-2), 97.8 (C-1), 109.4, $110.5\left(-\underline{C}\left(\mathrm{CH}_{3}\right)_{2}\right), 164.5,164.6\left(\mathrm{C}-2^{\prime}\right.$, C-5'). Anal. Calcd. for $\mathrm{C}_{14} \mathrm{H}_{20} \mathrm{~N}_{2} \mathrm{O}_{6}$ : C, 53.9; H, 6.4; N, 9.0. Found: C, 53.6; H, 6.5; N, 8.9\%.

2,3:4,5-Di-O-isopropylidene- $\beta$-D-arabino-hexos-2-ulo-2,6-pyranose benzoylhydrazone (8). A mixture of compound 2 (0.333 g, $1.29 \mathrm{mmol})$ and benzoylhydrazine $(0.203 \mathrm{~g}, 1.49 \mathrm{mmol})$ in 20 $\mathrm{mL}$ of $\mathrm{CH}_{2} \mathrm{Cl}_{2}$ was stirred overnight at room temperature. The solution was washed with $\mathrm{HCl}$ $1 \mathrm{~N}$, then with water, dried, filtered and evaporate under reduced pressure. The syrup was purified by dry flash chromatography, using mixtures of cyclohexane:acetone. Pure compound 8 was obtained as an amorphous solid (0.403 g). Yield 83\%; mp 151-152 ${ }^{\circ} \mathrm{C},[\alpha]_{\mathrm{D}}{ }^{20}-0.65\left(0.9, \mathrm{CHCl}_{3}\right)$, ${ }^{1} \mathrm{H}$ NMR $\delta 1.31,1.40,1.51$ (three s, $\left.12 \mathrm{H},-\mathrm{C}\left(\mathrm{CH}_{3}\right)_{2}\right), 3.67$ (d, $\left.J=13.0 \mathrm{~Hz}, 1 \mathrm{H}, \mathrm{H}-6 \mathrm{~b}\right), 3.86$ (d, $J$ $=13.0 \mathrm{~Hz}, 1 \mathrm{H}, \mathrm{H}-6 \mathrm{a}), 4.16(\mathrm{~d}, J=7.6 \mathrm{~Hz}, 1 \mathrm{H}, \mathrm{H}-5), 4.52(\mathrm{dd}, J=2.1 \mathrm{~Hz}$ and $7.9 \mathrm{~Hz}, 1 \mathrm{H}, \mathrm{H}-4)$, 4.78 (br s, 1H, H-3), 7.34-7.90 (m, 5H, aromatic protons), 7.97 (s, 1H, H-1), 9.99 (s, 1H, N $\underline{\mathrm{H}}$ ); ${ }^{13} \mathrm{C}$ NMR $\delta 24.3,26.0,26.1\left(-\mathrm{C}\left(\underline{\mathrm{CH}}_{3}\right)_{2}\right), 61.2(\mathrm{C}-6), 70.2$ (C-4), 70.5 (C-5), $71.9(\mathrm{C}-3), 101.3(\mathrm{C}-$ 2), $109.3\left(-\underline{\mathrm{C}}\left(\mathrm{CH}_{3}\right)_{2}\right), 127.5,128.5,130.3,131.9$ (aromatic carbons), $149.2(\mathrm{C}-1), 165.0(\mathrm{C}=\mathrm{O})$. Anal. Calcd. for $\mathrm{C}_{19} \mathrm{H}_{24} \mathrm{~N}_{2} \mathrm{O}_{6}$ : C, 60.6; H, 6.4; N, 7.4. Found: C, 60.3; H, 6.4; N, 7.5\%.

Heterocyclization of compound (8). Cyclization was made by heating a mixture of benzoylhydrazone $8(0.022 \mathrm{~g}, 0.07 \mathrm{mmol})$ with of acetic anhydride $(0.25 \mathrm{~mL})$ and of pyridine $(0.6 \mathrm{~mL})$ at $110{ }^{\circ} \mathrm{C}$. Reaction was stopped after $1 \mathrm{~h}$ by addition of ethanol, and following the same procedure used for compound 4 . The crude was analyzed by NMR and it was a mixture of compounds $9 \mathbf{a}$ and $9 \mathbf{b}$ in a $4: 1$ ratio as syrup.

5'S-1-( $N$-acetyl-2'-phenyl-4',5'-dihydro-1',3',4'-oxadiazol)-5'-yl-1,2:3,4-di-O-isopropylidene- $\beta$ D-arabinopyranose (9a). ${ }^{1} \mathrm{H}$ NMR $\delta 1.32,1.35,1.52,1.60$ (four s, $\left.12 \mathrm{H},-\mathrm{C}\left(\mathrm{CH}_{3}\right)_{2}\right), 2.33$ (s, 3H, 
$\left.\underline{\mathrm{CH}}_{3}-\mathrm{CO}-\right)$, 7.39-7.90 (m, 5H, aromatic protons); ${ }^{13} \mathrm{C}$ NMR $\delta 21.6$ ( $\left.\underline{\mathrm{CH}}_{3}-\mathrm{CO}-\right)$ 24.3, 25.3, 25.9, $26.4\left(-\mathrm{C}\left(\mathrm{CH}_{3}\right)_{2}\right), 61.6$ (C-5), 70.0 (C-3), 70.1 (C-4), 70.7 (C-2), 90.2 (C-5'), 103.1 (C-1), 109.3, $109.4\left(-\underline{\mathrm{C}}\left(\mathrm{CH}_{3}\right)_{2}\right), 124.5,127.1,128.5,131.5$ (aromatic carbons), $156.9\left(\mathrm{C}-5^{\prime}\right), 172.2(\mathrm{C}=\mathrm{O})$.

5'R-1-( $N$-acetyl-2'-phenyl-4',5'-dihydro-1',3',4'-oxadiazol)-5'-yl-1,2:3,4-di-O-isopropylidene- $\beta$ D-arabinopyranose (9b). ${ }^{1} \mathrm{H} \mathrm{NMR} \delta 1.32,1.34,1.37,1.54$ (four s, $\left.-\mathrm{C}\left(\mathrm{C}_{3}\right)_{2}\right), 2.46\left(\mathrm{~s}, 3 \mathrm{H}, \mathrm{C}_{3}\right.$ $\mathrm{CO}-)$, 7.39-7.90 (m, aromatic protons); ${ }^{13} \mathrm{C}$ NMR $\delta 23.2$ ( $\left.\mathrm{CH}_{3}-\mathrm{CO}-\right)$ 24.9, 26.0, 26.1, 26.3 ($\left.\mathrm{C}\left(\mathrm{CH}_{3}\right)_{2}\right), 61.2$ (C-5), 69.4 (C-3), 70.1 (C-4), 70.4 (C-2), 91.4 (C-5'), 101.1 (C-1), 109.2, 109.3 ($\left.\underline{\mathrm{C}}\left(\mathrm{CH}_{3}\right)_{2}\right), 127.4,128.8,129.7,133.9$ (aromatic carbons), $150.0\left(\mathrm{C}-5^{\prime}\right), 172.9(\mathrm{C}=\mathrm{O})$.

Synthesis of $5^{\prime} S-1-(N$-acetyl-2'-phenyl-4',5'-dihydro-1',3',4'-oxadiazol)-5'-yl-1,2:3,4-di-Oisopropylidene- $\beta$-D-arabinopyranose (9a). Compound 9a was made by heating a mixture of benzoylhydrazone $8(0.144 \mathrm{~g}, 0.38 \mathrm{mmol})$ with acetic anhydride $(1.5 \mathrm{~mL})$ and of pyridine $(2 \mathrm{~mL})$ at reflux. Reaction was stopped after $2 \mathrm{~h}$ by addition of ethanol, and following the same procedure used for compound 4 . The crude was purified by dry flash chromatography, using mixtures of cyclohexane:acetone and compound $\mathbf{9 a}$ was obtained as a syrup (0.136 g). Yield 85 $\%,[\alpha]_{D}{ }^{20}-2.28\left(0.9, \mathrm{CHCl}_{3}\right)$. Anal. Calcd. for $\mathrm{C}_{19} \mathrm{H}_{23} \mathrm{~N}_{2} \mathrm{O}_{6}: \mathrm{C}, 60.8 ; \mathrm{H}, 6.1 ; \mathrm{N}, 7.5$. Found: C, $60.9 ; \mathrm{H}, 6.3 ; \mathrm{N}, 7.5 \%$.

2,3:4,5-Di-O-isopropylidene- $\beta$-D-arabino-hexos-2-ulo-2,6-pyranose thiosemicarbazone (10). To compound $2(0.450 \mathrm{~g}, 1.74 \mathrm{mmol})$ dissolved in ethanol $(10 \mathrm{~mL})$, thiosemicarbazide $(0.192 \mathrm{~g})$ was added with stirring. The mixture was heated at reflux and the reaction was followed by TLC (cyclohexane:EtOAc 3:2). The solvent was evaporated and the syrup purified by dry flash chromatography, using mixtures of cyclohexane:acetone. Compound $\mathbf{1 0}$ was obtained as an amorphous solid (0.466 g). Yield 81\%; mp 98-100 ${ }^{\circ} \mathrm{C},[\alpha]_{\mathrm{D}}{ }^{20}-0.77\left(1.2, \mathrm{CHCl}_{3}\right),{ }^{1} \mathrm{H}$ NMR $\delta$ 1.32, 1.37, 1.40, 1.53 (three s, $\left.12 \mathrm{H},-\mathrm{C}\left(\mathrm{CH}_{3}\right)_{2}\right), 3.77$ (d, $J=13.0 \mathrm{~Hz}, 1 \mathrm{H}, \mathrm{H}-6 \mathrm{~b}$ ), 3.90 (dd, $J=1.7$ $\mathrm{Hz}$ and $13.0 \mathrm{~Hz}, 1 \mathrm{H}, \mathrm{H}-6 \mathrm{a}$ ), 4.25 (br d, $J=1.8 \mathrm{~Hz}$ and $7.6 \mathrm{~Hz}, 1 \mathrm{H}, \mathrm{H}-5$ ), 4.60 (dd, $J=1.8 \mathrm{~Hz}$ and $7.6 \mathrm{~Hz}, 1 \mathrm{H}, \mathrm{H}-4), 4.62$ (d, $J=2.8 \mathrm{~Hz}, 1 \mathrm{H}, \mathrm{H}-3), 6.81-7.19\left(2 \mathrm{~s}, 2 \mathrm{H},-\mathrm{N}_{2}\right), 7.39$ (s, 1H, H-1), $10.20(\mathrm{~s}, 1 \mathrm{H},-\mathrm{N} \underline{\mathrm{H}}-) ;{ }^{13} \mathrm{C}$ NMR $\delta 24.3,25.0,26.1,26.9\left(-\mathrm{C}\left(\underline{\mathrm{CH}}_{3}\right)_{2}\right), 61.1(\mathrm{C}-6), 70.0(\mathrm{C}-4), 70.3$ (C-5), 72.2 (C-3), 100.8 (C-2), 109.2, $109.3\left(-\underline{\mathrm{C}}\left(\mathrm{CH}_{3}\right)_{2}\right), 143.4(\mathrm{C}-1), 179.3(\mathrm{C}=\mathrm{S})$. Anal. Calcd. for $2\left(\mathrm{C}_{13} \mathrm{H}_{21} \mathrm{~N}_{3} \mathrm{O}_{5} \mathrm{~S}\right) . \mathrm{H}_{2} \mathrm{O}$ : C, 45.9; $\mathrm{H}, 6.5 ; \mathrm{N}, 12.4$. Found: $\mathrm{C}, 46.2 ; \mathrm{H}, 6.4 ; \mathrm{N}, 12.2 \%$.

1-(2'-Amino-1',3', 4'-thiadiazol)-5'-yl-1,2:3,4-di- $O$-isopropylidene- $\beta$-D-arabinopyranose (11). Compound $10(0.298 \mathrm{~g}, 0.90 \mathrm{mmol})$ was dissolved in pyridine $(30 \mathrm{~mL})$ and $\mathrm{FeCl}_{3} \cdot 6 \mathrm{H}_{2} \mathrm{O}$ (solution $2 \mathrm{M}$ in ethanol) $(3.3 \mathrm{~mL})$ was added with stirring. The mixture was heated for $10 \mathrm{~min}$, then evaporated, suspended in ethanol, filtered trough a silica pad, evaporated, suspended in acetone, filtered and evaporated. The residue was purified by dry flash chromatography, using mixtures of cyclohexane:acetone $(0.153 \mathrm{~g})$. Yield $51 \%$; mp $185-187^{\circ} \mathrm{C},[\alpha]_{\mathrm{D}}{ }^{20}-0.56\left(0.9, \mathrm{CHCl}_{3}\right),{ }^{1} \mathrm{H}$ NMR $\delta 1.33,1.37,1.57$ (three s, $12 \mathrm{H},-\mathrm{C}\left(\mathrm{CH}_{3}\right)_{2}, 5.62$ (br s, $\left.2 \mathrm{H},-\mathrm{NH}_{2}\right) ;{ }^{13} \mathrm{C} \mathrm{NMR} \delta 24.1,25.0,25.9$, $26.2\left(-\mathrm{C}\left(\underline{\mathrm{CH}}_{3}\right)_{2}\right), 61.8(\mathrm{C}-5), 70.2$ (C-3), 70.4 (C-4), 73.9 (C-2), $100.7(\mathrm{C}-1), 109.3,110.1$ ($\left.\underline{\mathrm{C}}\left(\mathrm{CH}_{3}\right)_{2}\right), 161.5,169.5\left(\mathrm{C}-2^{\prime}\right.$ and $\left.\mathrm{C}-5^{\prime}\right)$. Anal. Calcd. for $\mathrm{C}_{13} \mathrm{H}_{19} \mathrm{~N}_{3} \mathrm{O}_{5} \mathrm{~S}: \mathrm{C}, 47.4 ; \mathrm{H}, 5.8 ; \mathrm{N}, 12.8$. Found: C, 47.4; H, 5.9; N, 12.7\%. 


\section{Heterocyclization of compound (10)}

Compound $10(0.394 \mathrm{~g}, 1.19 \mathrm{mmol})$ was dissolved in pyridine $(3 \mathrm{~mL})$ and then acetic anhydride $(3 \mathrm{~mL})$ was added with stirring. The mixture was heated at $110{ }^{\circ} \mathrm{C}$ for $2 \mathrm{~h}$ and the reaction was stopped and processed in the same way than for compound 4. The crude residue was disaggregated with water and a greenish-yellow precipitate was obtained. Crystallization from ethanol yields product $12(0.272 \mathrm{~g}, 0.65 \mathrm{mmol})$ as a mixture of two diastereoisomers 12a and 12b in a 5:2 relationship, determined by ${ }^{1} \mathrm{H}$ NMR Yield 55\%; mp 244-248 ${ }^{\circ} \mathrm{C}$. Anal. Calcd. for $\mathrm{C}_{15} \mathrm{H}_{22} \mathrm{~N}_{3} \mathrm{O}_{6} \mathrm{~S}: \mathrm{C}, 49.2 ; \mathrm{H}, 6.0 ; \mathrm{N}, 10.1$. Found: C, 48.8; H, 6.0; N, 10.0\%.

$\mathbf{5}^{\prime} \boldsymbol{R}$-1-( $\boldsymbol{N}$-acetyl-2'-acetamide-4',5'-dihydro-1',3',4'-thiadiazol)-5'-yl-1,2:3,4-di-O-isopropylidene$\beta$-D-arabinopyranose (12a). ${ }^{1} \mathrm{H}$ NMR $\delta 1.30,1.45,1.46,1.50$ (four $\left.\mathrm{s}, 12 \mathrm{H},-\mathrm{C}\left(\mathrm{C}_{\mathrm{H}_{3}}\right)_{2}\right), 2.17$, 2.18 (two s, $6 \mathrm{H}, \mathrm{CH}_{3} \mathrm{CO}-$ ), 8.52 (br s, $1 \mathrm{H},-\mathrm{N} \underline{\mathrm{H}}-$ ); ${ }^{13} \mathrm{C} \mathrm{NMR} \delta 21.8,23.3$ ( $\mathrm{CH}_{3} \mathrm{CO}-$ ), 23.8, 25.3, 25.9, $26.0\left(-\mathrm{C}\left(\underline{\mathrm{CH}}_{3}\right)_{2}\right), 61.3(\mathrm{C}-5), 70.2\left(\mathrm{C}-5^{\prime}\right), 70.3$ (C-4), 70.4 (C-3), 71.6 (C-2), 104.2 (C-1), 108.2, $108.7\left(-\underline{\mathrm{C}}\left(\mathrm{CH}_{3}\right)_{2}\right), 149.0\left(\mathrm{C}-2^{\prime}\right), 168.1,171.0(\mathrm{C}=\mathrm{O})$.

$5^{\prime} S$-1-( $N$-acetyl-2'-acetamide-4',5'-dihydro-1',3',4'-thiadiazol)-5'-yl-1,2:3,4-di-O-isopropylidene$\beta$-D-arabinopyranose (12b). ${ }^{1} \mathrm{H}$ NMR $\delta 1.33,1.36,1.51,1.57$ (four s, $\left.12 \mathrm{H},-\mathrm{C}\left(\mathrm{C}_{3}\right)_{2}\right), 2.21$, 2.22 (two s, $6 \mathrm{H}, \mathrm{CH}_{3} \mathrm{CO}-$ ), 8.97 (br s, $1 \mathrm{H},-\mathrm{N} \underline{\mathrm{H}}-$ ); ${ }^{13} \mathrm{C} \mathrm{NMR} \delta 22.1,23.2$ ( $\mathrm{CH}_{3} \mathrm{CO}-$ ), 24.2, 24.5, 26.1, $26.3\left(-\mathrm{C}\left(\underline{\mathrm{CH}}_{3}\right)_{2}\right), 62.1(\mathrm{C}-5), 68.0\left(\mathrm{C}-5^{\prime}\right), 69.9$ (C-2), 70.3 (C-3), 70.7 (C-4), 103.6 (C-1), 109.2, $109.5\left(-\underline{C}\left(\mathrm{CH}_{3}\right)_{2}\right), 150.8\left(\mathrm{C}-2^{\prime}\right), 168.1,171.0(\mathrm{C}=\mathrm{O})$.

\section{Acknowledgements}

The authors acknowledged CONICET (PIP 5011), ANPCyT (PICT 13922) and UBA (X058) for financial support. NBD is a Research Member of the CONICET.

\section{References}

1. Spina, E.; Perugi, G. Epileptic Disord. 2004, 6, 57.

2. (a) Kinga K. Borowicz, K. K.; Kleinrok, Z.; Czuczwar, S. J. Eur. J. Pharmacol. 1997, 327, 125; .b) Kinga K. Borowicz, K. K.; Kleinrok, Z.; Czuczwar, S. J. Eur. J. Pharmacol. 1997, 331, 127. (c) Zhao, L.-X.; Park, J. G.; Moon, Y.-S.; Basnet, A.; Choi, J.; Kim, E.-k.; Jeong, T. Ch.; Jahng, Y.; Lee, E.-S. Il Farmaco, 2004, 59, 381. (d) Malawska, B. Curr. Top. Med. Chem. 2005, 5, 69.

3. Maryanoff, B. E.; Nortey, S. O.; Gardocki, J. F.; Shank, R. P.; Dodgsons, S. P. J. Med. Chem. 1987, 30, 880 .

4. Shank, R. P.; Gardocki, J. F; Streeter, A. J.; Maryanoff, B. E. Epilepsia 2000; 41, 2000.

5. White, H. S.; Brown, S. D.; Woodhead, J. H.; Skeen, G. A.; Wolf, H. H. Epilepsy Res. 1997, $28,167$.

6. Gibbs, $3^{\text {rd }}$ J.W.; Sombati, S.; DeLorenzo, R. J.; Coulter, D. A. Epilepsia 2000, 41, 10. 
7. Taverna, S.; Sancini, G.; Mantegazza, M.; Franceschetti, S.; Avanzini, G. J. Pharmacol. Exp. Ther. 1999, 288, 960.

8. Gryder, D. S.; Rogawski, M. A. J. Neurosci. 2003, 23, 7069.

9. Latini, G.; Verrotti, A.; Manco, R.; Scardapane, A.; Del, V. A.; Chiarelli, F. Mini Rev. Med. Chem. 2008, 8, 10.

10. Perucca, E. Pharmacol. Res. 1997, 35, 241.

11. Shank, R. P.; Maryanoff, B. E. Neurosci. Therap. 2008, 14, 120.

12. Baltieri, D. A.; Daro, F. R.; Ribeiro, P. L.; De Andrade, A. G. Addiction 2008, 102, 2035.

13. Khazaal, Y.; Cornuz, J.; Bilancioni, R.; Zullino, D. F. Psychiatry Clin. Neurosci. 2006, 60, 384.

14. Supuran, C. T.; Di, F. A.; De, S. G. Emerg. Drugs 2008, 13, 383.

15. Lee, H.-W.; Jung, D.-K.; Suh, Ch.-K.; Kwon, S.-H.; Park, S.-P. Epilepsy Behav. 2006, 8, 736.

16. Kockelmann, E.; Elger, Ch. E.; Helmstaedter, Ch. Epilepsy Res. 2003, 54, 171.

17. Beer, B.; Libiseller, K.; Oberacher, H.; Pavlic, M.; Forensic Sci. Int. 2010, 202, e9.

18. (a) Temperini, C.; Innocenti, A.; Scozzafava, A.; Parkkila, S.; Supuran, C. T. J. Med. Chem. 2010, 53, 850. (b) Moreira Lima, L.; Barreiro, E. J., Curr. Med. Chem. 2005, 12, 23.

19. (a) Johansson, A.; Poliakov, A.; Akerblom, E.; Wiklund, K.; Lindeberg, G.; Winiwarter, S.; Danielson, U. H.; Samuelsson, B.; Hallberg, A. Bioorg. Med. Chem. 2003, 11, 2551. (b) Aberg, V.; Das, P.; Chorell, E.; Hendenström, M.; Pinkner, J. S.; Hultgren, S. J.; Almqvist, F. Bioorg. Med. Chem. Lett. 2008, 18, 3536.

20. (a) Rönn, R.; Gossas, T.; Sabnis, Y. A.; Daoud, H.; Akerblom, E.; Danielson, U. H.; Sandström, A. Bioorg. Med. Chem. 2007, 15, 4057. (b) Krungkrai, J.; Krungkrai, S.; Supuran, C. T. Bioorg. Med. Chem. Lett. 2008, 18, 5456.

21. Izquierdo Cubero, I.; Plaza Lopez-Espinosa, M. T. Carbohydr. Res. 1990, 205, 293.

22. (a) Martins Alho, M. A.; D’Accorso, N. B. J. Heterocycl. Chem. 1999, 36, 177. (b) Martins Alho, M. A.; Errea, M. I.; Sguerra, V. L.; D’Accorso, N. B. Talarico, L. B.; García C. C.; Damonte, E. B. J. Heterocycl. Chem. 2005, 42, 979.

23. Martins Alho, M. A.; D’Accorso, N. B. J. Heterocycl. Chem. 1997, 34, 1415.

24. Martins Alho, M. A.; D’Accorso, N. B. J. Heterocycl. Chem. 2007, 44, 901. 